\title{
What reality for animals in the Mesopotamian medical texts? Plant vs animal
}

Vérène CHALENDAR

UMR 7192 Proche-Orient - Caucase : langues, archéologie, cultures, Collège de France, 52 rue du Cardinal Lemoine,

F-75005 Paris (France)

et LabEx HASTEC Histoire et anthropologie des savoirs, des techniques et des croyances, École Pratique des Hautes Études, 4-14 rue Ferrus,

F-75014 Paris (France)

verene.chalendar@gmail.com

Published on 30 December 2016

Chalendar V. 2016. - What reality for animals in the Mesopotamian medical texts? Plant vs animal. Anthropozoologica 51 (2): 97-103. http://doi.org/10.5252/az2016n2a2

\section{ABSTRACT}

Animals are often mentioned as ingredients in the medical cuneiform tablets. This paper summarizes several aspects implied by the study of Fauna in the frame of Mesopotamian medicine. It consists of a brief introduction, focusing on three main aspects: firstly, what we find in the Assyro-Babylonian

KEY WORDS

Medicine, taxonomy animals, materia medica,
Mesopotamia.

MOTS CLÉS

Médecine,

taxinomie,

animaux,

materia medica,
Mésopotamie. medical texts regarding animals; then, we will make a short presentation of the Decknamen theorie, which assumes that some animal names could in fact designate plants. The consequences of such a hypothesis are examined along with our methods to prove or disprove this theory on a case-by-case study; finally, we will state preliminary conclusions about the use of animals and their products in the Assyro-Babylonian medicine.

\section{RÉSUMÉ}

Quelle réalité pour les animaux dans les textes médicaux mésopotamiens? Plantes vs animaux.

Les animaux apparaissent souvent comme ingrédient dans les tablettes médicales cunéiformes. Cet article a pour but de synthétiser quelques résultats induits par notre étude de la faune dans le cadre de la médecine mésopotamienne. Après une brève introduction, trois points seront abordés: en premier lieu, ce que nous trouvons dans les textes médicaux assyro-babyloniens concernant les animaux; puis nous ferons une courte présentation de la théorie des Decknamen, qui suggère que certaines qualifications animales pourraient, en réalité, désigner des plantes. Quelles sont les conséquences d'une telle hypothèse et quelle méthode adopter pour vérifier la pertinence de cette théorie à partir d'une étude au cas par cas ? Enfin, nous présenterons nos conclusions provisoires sur l'emploi des animaux et de leurs produits dans la médecine assyro-babylonienne. 


\section{INTRODUCTION}

Mesopotamian culture is well-known for its abundant textual documentation. These texts were written on clay tablets, thanks to the cuneiform writing system ${ }^{1}$. During the Assyrian domination, and especially the reign of Assurbanipal (c. 669630 (-627) BC), huge libraries (Pedersén 1998: 129-181) were established and numerous scientific texts were compiled. Consequently, the majority of the medical texts we have are dated back to this period (911-612 BC), even if they sometimes record older contents such as recipes claimed from Hammurabi's time (1792-1750 BC). Indeed, under the Assyrian period, we are probably witnessing a process of redaction of ancient orally transmitted traditions (few colophons mention ancient times - some of them alluding to oral tradition of antediluvian times, supposedly in an optic of legitimation, see Geller 2010: 17).

Medical texts are numerous and can be sorted into several categories. In this paper, I will mostly discuss the therapeutic texts. This kind of texts reports recipes of drugs for specific pathologies that are clearly stated. Therapeutic texts are, in theory, organised in several parts clearly identifiable (Herrero 1984: 21):

- a clinical indication, which consists of symptoms exposition and potentially a diagnosis;

- a transition formula, such as "in order to cure him", followed by the listing of ingredients with sometimes operations of preparation that should be performed, and finally the mode of administration;

- possibly a vital prognosis which is generally positive.

Drugs could gather three main categories of ingredients: minerals, plants, and animals. These classes of ingredients can either be employed separately (recipes using only stones or plants for instance), either combined amongst themselves (recipes made up of ingredients of various natures). Although plants are the most frequently attested kind of ingredient, animals play a specific and significant role in the preparation of remedies.

This paper aims at displaying briefly the place of animals in the Mesopotamian medicine by presenting what we find in textual documentation, such as general information on species, but also their specific use as materia medica. It will also broach issues I encountered and especially the confrontation with the Decknamen theorie, a hypothesis that widely affects the comprehension of medical texts by suggesting that some ingredients have "cover names" (Decknamen). Although this article deals with medicine intended for men, one should note that veterinary practices were already attested especially for equids and cattle (e.g., Stol 2011; Scurlock 2014: 498, 499). Some of these prescriptions are rather close to treatments applied to humans, consequently animal materia medica could also be used. The hippiatric textual genre that emerged in the Ancient Near-East (as attested in

1. For a better readability, in the main text, Akkadian terms are in italics whereas Sumerian terms in UPPER-CASE letters. However, in transliterations Akkadian will be written in italics and sumerograms in regular lower-case letters (upper-case letters are formally reserved for signs which value is still undefined).
Babylonian and Ugaritic documentation, cf. Loretz 2011) has been received with a great attention by later medicines (e.g., McCabe 2007 for Byzantine corpus; Heide 2008: 43-45 for the medieval Arabic hippiatric corpus). This paper is based on my current $\mathrm{PhD}$ research; some of these results are preliminary and consequently subject to change with the emerging of new data.

\section{THE DIFFERENT USES OF ANIMALS IN THE THERAPEUTIC APPROACHES}

The study of animals as materia medica reveals the complexity of the Mesopotamian medicine through the different roles animals used to assume, but also through the difficult interpretation of certain ingredient names. Concerning the various status of animals in medical treatments, several remarks should be made:

In certain cases, animals become a substitute for the patient. In such a therapeutic approach the animal plays the role of a new receptacle for the illness, which affects someone. Transfers in rituals have been discussed by Scurlock (2002). For instance, in some rituals an animal is caught, and put physically or symbolically in contact with the patient, in order to transfer the disease from the sick man's body to the animal's. Afterwards, the animal is released in order to carry away the sickness.

The prescription AMT 88,2, unfortunately partially broken, relates how a patient could be relieved from its illness by a complex therapeutic ritual, including a step that consists of capturing a frog, talking to it and probably (the passage is missing) putting it back into the river. Another illustration of this method could be observed in the text BAM IV-396: iv 22-23. "Prescription No.3: Seize a live giritu-fish, (the patient) will urinate onto its head, you will release it into the canal and he will get better." (Translation by Geller 2005: 40-41).

In these two examples, animals stayed alive but they were not always so lucky. In AMD III, Scurlock (2006: 55) gives a commentary on the text LKA 85: 1-25. This text exposes a treatment against the act of an "evil ghost". In order to release the patient from this uncomfortable situation, a goose had to be slaughtered and its heart placed on the patient's chest while the āšipu was reciting an incantation. I will not go further on this prescription that has already been widely commented, but obviously the goose did not survive this process!

Animals could also be employed for symbolical and/or magical reasons. In this specific therapeutic approach, the healer seeks to transfer a particular property of an animal to a patient who needs it (for example, the sexual vigour of a stag will be transferred to an impotent man).

These symbolical connections could be enlightened by incantations, that are sometimes really indicative of the perception of certain animals by the Mesopotamian people. For instance, see this excerpt of incantation for potency issues translated by Biggs (1967: 22): 


\author{
"Incantation. Get excited! Get excited! Get an erection! \\ Get an erection lik[e a wild bull]! \\ ${ }^{2}$ Get excited like a stag! ..."
}

The analysis of the animal ingredients and even more so the symbolical reasons of their usage in the context of Mesopotamian medicine implies an extensive study of the cultural background. For instance, in the Mesopotamian society the scorpion was considered as a bringer of fecundity and fertility (among other references: Pientka-Hintz 2004: 397; Battini 2006: 14). Such positive notions associated with this frightening animal seem quite surprising to our modern mentality.

Anyway, trying to transfer a specific property from an animal to a patient, or conversely transmitting the illness from a patient to an animal, all these belong to sympathetic magic. Another example could be observed when a specific animal part is used for the treatment of the analogous human sick body part.

We are certainly more familiar with the latest usage of animal we noticed. This usage is motivated by the observation of an eventual medical efficiency. We would term it an "active ingredient" or a "pharmacodynamic property" after our modern vocabulary.

This paper will not display animals as offerings through sacrifice, because even if they can contribute to some extent to treatment procedures, they do not belong to the pharmacopeia stricto sensu (for an example of this kind of procedures see Verderame 2013). These few points resume briefly different aspects assumed by animals in the frame of Mesopotamian medicine. A careful scrutiny of the therapeutic texts in which animal ingredients are mentioned allows us to foresee an explanation of their use.

\section{MATERIA MEDICA AND FAUNA}

Concerning what could be found in the Mesopotamian medical corpus: animals are abundant and all orders are represented from the tiniest one (insects, arthropods...) to the biggest one (mammals). Domestic and wild species were both employed. A large array of ingredients coming from animals was used: parts of the body and organs (eye, kidney, testicle, gall...), hairs, skin, leather, scale, bodily secretions (blood, sperm, saliva ) urine, excrements...

However, the use of certain ingredients is quite rare and seems linked to specific pathologies. Note also the peculiar use of meat that never enters in remedies composition, except in a few apparent "nutritional recommendations" that could be related with the hemerological texts which can present dietary instructions (restrictive or on the contrary incentive according to the calendar).

The Mesopotamian taxonomy (Streck 2014: 16-19) is manifested among other sources through lexical lists which give us numerous animal names in Sumerian but also by providing their Akkadian equivalent starting from the Kas- site period (for the HAR-ra = hubullu list, Veldhuis 2014: 250). General terms were employed to refer to animals, for instance in Sumerian NÍG.ÚR.LÍMMU.BA, which literally means "thing with four legs" seems to point to the quadrupeds, and its Akkadian equivalent nammašsûu (Streck 2014: 16). A major classification criterion seems to be the proximity with humans, that way domestic animals are mentioned first in a rather canonical order:

- ovine and caprine;

- bovine;

- equine.

Then, a second category gathers wild species. The internal logic of these lists is motivated by several criteria; the most obvious being an ordering by morphological similarities which also motivates the written form of their Sumerian names (Cavigneaux 1983: 626, talks about a thematic and acrographic way of ordering elements). Transitions between different animal families seem also legitimated by a careful observation of species such as behavioural factors, natural environment or even food chain.

Studying the taxonomy is primordial; it helps to shed light on the links between taxonomy and enumeration of ingredients in medical recipes. For instance, note that lion, wolf, dog and fox are practically always mentioned together in prescriptions, interestingly this same group of animals can be observed in lexical lists which helped us to establish the taxonomy (Chalendar in press).

BAM III-311: 35

Clinical indication: cf. 30' "ana šu dinanna la-zi zi-hi

35 diš ki.min síg ur.mah síg ur.bar.ra síg ka $\mathrm{k}_{5}$. a síg ur.gi ge $_{6}$ ina kuš

"35'If ditto (30'in order to remove the 'Hand of Ištar' which persists): (you will wrap) lion hair, wolf hair, fox hair, black dog hair, in a skin.”

BAM V-469: $14^{\prime}-17^{2}$

Clinical indication: cf. 35" "[x ni] gin $18 q u_{5}$-tàru šs $[a$ šu.gidi] $\mathrm{m}_{\mathrm{X}}$.ma."

14 [... še $\mathrm{e}_{10}$ ? ur.]bar.ra še $\mathrm{e}_{10}$ šah še $\mathrm{s}_{10} \mathrm{ka}_{5}$. a gìr.p [ad.d] $\mathrm{u} \mathrm{ka} \cdot \mathrm{a}$

15 [gìr.pad.du?...] gìr.pad.du nam.lú.u ${ }_{18} \cdot l u[s] \mathrm{i} \mathrm{gu}_{4}$

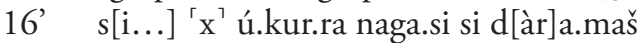

$17^{\prime}$ sí $\left[\mathrm{g}^{\text {? }} . . \mathrm{ba}\right] \mathrm{r}$ muš ina ì.udu éllag gu $\mathrm{gu}_{4}$ he.he $[i] n a$ dè

“ 35 '([To]tal: 18 fumigations o[ $\mathrm{f}$ the 'Hand of the gh] ost') 14 ' [...wo]lf [faeces?], porc faeces, fox faeces, fox bon[e], $15^{\prime}$ 'bone...], human bone, ox [ho] rn, ${ }^{1}$ 'ho[rn ...], ninn $\hat{u}-$ plant, salicornia, $s[\mathrm{ta}] \mathrm{g}$ antler, ${ }^{17}$ 'hai[r? of..., slou $] \mathrm{gh}$ of a snake. You will mix in ox kidney fat. (You will fumigate him) [o]ver the embers ${ }^{3}$."

2. This text has been edited by Scurlock (2006: 573), it is presented here slightly revised.

3. Concerning this developed translation of "ina dè", see our note about the use of elliptic formula in paragraph The feasibility of drug. 
General studies on the Mesopotamian fauna are quite old in Assyriology. Landsberger was a pioneer in this field with several studies $(1934,1960,1962)$ in which he suggested numerous identifications of animal species. Salonen took over from Landsberger's work with his studies about fishing (1970), birds (1973) and hunting (1976).

Identification is a difficult task that is nowadays a little bit simplified, with the help of new tools, especially archaezoology - some of these propositions can be either reaffirmed or disqualified. A few works are now reassessing these first identifications or attempting to precise them (Heimpel 1987; Lion \& Michel 2000; Lion et al. 2000; Kogan 2005...)

\section{REAL ANIMALS, ENCRYPTED KNOWLEDGE OR POPULAR NAMES FOR PLANTS?}

Once we are done with the identification step, another thorny task arises: Köcher (1995: 203-217) stated that Mesopotamian scribes used to encrypt information of medical tablets. Some animal designations could in fact refer to plants, in order to hide knowledge from non-insiders. He labelled this theory, Decknamen theorie which could be translated by "cover names" or "coded names" theory.

This theory is based on the lexical list called Uruanna (or Irianna), which is supposed to provide vegetal equivalents for animal designations. It has been the subject of many discussions between researchers.

Kinnier Wilson (2005: 45-51) suggested to see popular names rather than "coded names". For him, we are not in an esoteric context, but quite the opposite in a popular level of language. He wrote "Why some plant names were regarded as 'secret' and others not?" (Kinnier Wilson 2005: 48).

The consequences of such theory are numerous and heavy: first of all, this theory impacts widely on the comprehension of the Mesopotamian transmission of knowledge. Were these "scientific" texts encrypted and did they took place in an esoteric context, or were they understandable by everybody? Secondly, it affects the composition of the Mesopotamian pharmacopeia. If such hypothesis is correct, the part of the animal ingredients in the Mesopotamian pharmacopeia should be adjusted downwards.

Most of the time, ingredients have been judged suspect on account of their nonappealing aspect: Frog's gall, dove's excrements, dried shrew, urine of cow or even snake or gecko's blood...

One problem of the cuneiform medical texts is that they rarely precise the amount of ingredients that should be used (this same phenomenon occurs for cooking recipes, see Bottéro 1995). This indication would be an invaluable help to determine the real nature of the ingredients. But is this argument of "repulsive ingredients" really admissible? The use of such substances is widely attested in traditional medicine, and also in the magical approach without any re-assessment!
The Decknamen theory continues to divide assyriologists; some of them favor the existence of such coded designations.

Geller (2010: 53) sees in those cover names a way to "prevent poaching of patients by quacksalvers", whereas others are less skeptical about the eventual therapeutic usage of non-appealing ingredients. Likewise, Scurlock (2006: 63) writes:

"It should, however, be noted that what looks 'suspicious' to us may have a perfectly valid medical reason behind it. One would hardly suspect that snake skin could be anything but a 'magical' ingredient, yet scientific tests have shown it to contain zinc and titanium oxide in medically significant quantities. Neither should we allow negative attitudes to natural bodily functions to obscure the potential medical uses of urine and various types of excrement."

This matter must be solved, but how? What methods could be employed to prove, disprove or shade this theory?

Once the listing of animal ingredients has been established and a documentation as exhaustive as possible for each doubtful ingredient has been gathered, every prescription should be examined in order to find what could betray the use of a plant behind an animal designation. It is a long process, and several criteria must be explored, I shall dwell a bit more here on some of them:

\section{THE ACCESS TO THE SUBSTANCE}

Several questions come to our mind: Was the animal common on the Mesopotamian territory? Is it easy to find in such quantity that is in harmony with its frequency of occurrence in the text? Was the access to the substance dangerous? We find for example that lion's fat is frequently used in our text. This ingredient seems not so safe to obtain.

\section{THE FEASIBILITY OF THE DRUG}

This criterion is defined on the basis of the analysis of verbs describing the operations of preparation applied to animals. Indeed, some recipes precise how to prepare the animal. However, one should note the possible use of elliptic formulations.

For instance, recipes for fumigations often use a canonical formula consisting in the enumeration of ingredients followed by "ina dè" which could be translated as "over the embers" and tacitly means "(you fumigate him) over the coals/ embers". The same thing can be observed for therapeutic/ prophylactic "amulets" that consist of leather bags containing materia medica. The formulation of these "amulets" uses the elliptic formula ina kuš ("in a skin") to say "(you put all these ingredients) in a leather bag (and place it around the neck of the patient)".

Anyway, sometimes, we do find operations of preparation and even succession of actions which point to an animal or a plant. Some verbs seem totally incompatible with the hypothesis of a plant behind an animal. 
For instance:

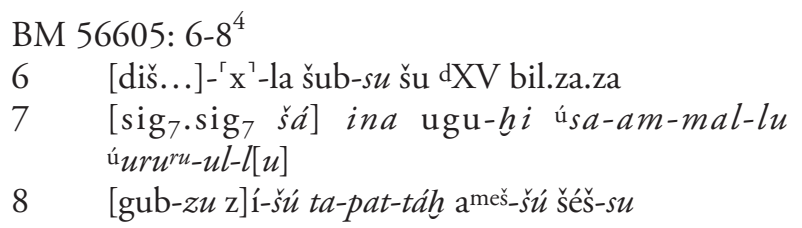

“6[If...] descends upon him, 'Hand of Ištar': 7 [brown] ${ }^{6}$ frog $8[$ which stands $]$ 7on a samallu-plant (or) an urul $[l u]$ plant. ${ }^{8}$ You will pierce its [ga]ll(bladder). You will rub him (with) its discharge."

In return, some prescriptions mention operations of preparation which would seem odd if applied to an animal.

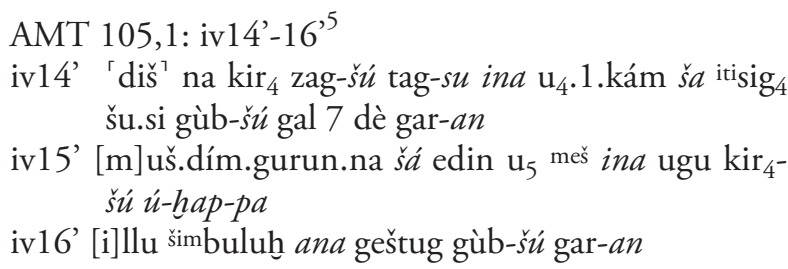

"iv14' If the right nostril of a man is causing him a throbbing pain: on the first day of the month-simânu (may-june) he will put its left thumb (upon?) 7 coals. iv15'He will crush mating steppe [piz]allüru-lizards on his nose. iv16 He will put galbanum [re]sin in his left ear."

\section{IS THE MOTIVATION OF THE USE OF THE INGREDIENT CLEAR?}

As I already exposed, ingredients were used for several reasons, among them, symbolical motives: the prescription AO 7682 advises to treat a scorpion's sting by rubbing the viscera of the animal directly on the wound. In that treatment "fire is fought with fire" and even if the mention of scorpion is often considered as part of this "secret" or "alternative" names, in this case, it is quite clear that it is the animal that was employed.

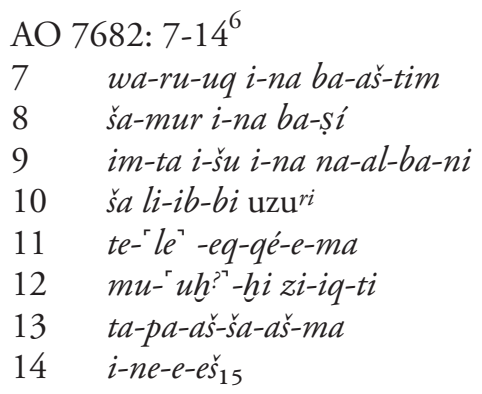

4. This text has been edited by Heeßel $(2000: 117,118)$ - translation by the author.

5. This text has also been edited by Scurlock (2014: 388) - edition by the author.

6. This text has been edited Nougayrol (1972: 141-143) (editio princeps) slightly revised here.
"It is green in bushes. ${ }^{8}$ It emerges from sand. $9 / \mathrm{t}$ has venom; it (is even!) in the brick mould. ${ }^{10}$ This (the scorpion) of which ${ }^{11}$ you will take ${ }^{10}$ the inside of (its) flesh. ${ }^{13}$ You will rub ${ }^{12}$ the sting surface (with it) and 14 he (the patient) will recover."

\section{Philological arguments}

Numerous animal ingredients are mentioned in Uruanna opposite a vegetal name. These two terms facing in (the animal on the one hand and the plant on the other hand) have been interpreted as popular names or even coded names for a same substance supposed to be vegetal. These hypotheses postulate equivalence on a semantic basis.

We could also suggest another hypothesis such as equivalences of a different kind: for instance a substitute in case of one ingredient is missing, ingredients supposed to have the same medical effect would be placed face to face (Scurlock 2014: 291).

If we choose to follow the Decknamen theory and consequently to believe that these two designations mentioned in Uruanna are different names for a single substance, therefore we could not find together in the same prescription the plant designation and its supposed alternative name. Indeed, it would imply a duplication of ingredient and we could suspect a scribal error!

\section{CONCLUSIONS}

Studying the fauna through the prism of medical texts has significant consequences. At first, the analysis of the usage of animals as materia medica illustrates better than any other kind of ingredients the different mechanisms that could be found in the Mesopotamian medicine:

- the use of an ingredient for its pharmacological property; - the use of an ingredient for magico-symbolical reasons; - the use of an ingredient to provide a substitute to the sick man (this third mechanism is only suitable for animals, it is not provided by any other kind of ingredients because it requires a living being).

Secondly, it reveals the omnipresence of the animal in the pharmacopeia. To this day, about 80 animals have been listed in the therapeutic texts as ingredients; many body parts, products or even bodily secretions are employed. Each animal seems to have a specific range of ingredients extracted from them and those ingredients can be recurrent in the treatment of precise pathologies (for instance, eye pathologies are regularly treated with bat's guano, ostrich eggshells seems to play a particular role in renal diseases, mice seem appreciated for the treatment of epilepsy or closely-related diseases...).

Finally this subject is inseparable from the discussion around the Decknamen theorie. Personally, I will not be too definitive about the interpretation or even the role to give to Uruanna. Nevertheless, I'm not convinced by the assumption of an encrypted knowledge proposed by Köcher, thus, I am inclined to agree with the suggestion of Kinnier Wilson, who chose to see alternative names rather than real coded names. Indeed, 
as Kinnier Wilson already suggested, a partial code seems inappropriate to preserve the secrecy of knowledge, but also because the ingredients supposed to be encrypted appears to be really common in the Mesopotamian medicine. At least, this document could contain several logics that allow us to give some credit to other assumptions such as the possibility of therapeutic substitutes.

Concerning the assumption of "popular designations", even if the approximation between the Mesopotamian "dog's tongue" ingredient and our modern cynoglossum seems easy (better be careful about the analogy of images). It is obvious that animal comparisons were used in Mesopotamia to elaborate a botanical terminology.

Nowadays, we are still familiar with this logic (dandelion comes from the French "dent-de-lion" - lion's tooth). It is noteworthy that this same plant - dandelion or taraxacum officinalis - can also be named in popular French: "dent-delion" (lion's tooth), "laitue de chien" (dog's lettuce) or even "salade de taupe" (mole's salad).

Fauna offers a wide range of characteristic forms, textures that allows evocative comparisons (see the šammu šikinšu list - Stadhouders 2011: 2012) and could end up with popular names. That way, some of the animal parts mentioned in our texts are most likely plants.

To conclude I would say that these "alternative names", are part of course, of the Mesopotamian pharmacopeia but do not in any case exclude the use of real animals. For instance in the therapeutical rituals animals predominate widely.

\section{Acknowledgements}

I sincerely thank $\mathrm{D}$. Charpin for the supervision of my PhD, and L. Marti for sharing his remarks about this paper. I also express my gratitude to the two anonymous reviewers for their comments and suggestions.

\section{REFERENCES}

BATTini L. 2006. - Les images de la naissance en Mésopotamie, in BatTini L. \& Villard P. (eds.), Médecine et médecins au Proche-Orient ancien. Actes du colloque international organisé à Lyon les 8 et 9 novembre 2002, Maison de l'Orient et de la Méditerranée. British Archaeological Reports International Series 1528: $1-37$.

BIGGS R. 1967. - ک̌À.ZI.GA: Ancient Mesopotamian Potency Incantations. Texts from Cuneiform Sources 2. Locust Valley, New-York, 86 p. BOTTÉRO J. 1995. - Textes culinaires mésopotamiens. Eisenbrauns, Winona Lake, 252 p. (Coll. Mesopotamian Civilizations; 6.)

CAVIGNEAUX A. 1983. - Lexikalische Listen, in EDZARD D. (ed.), Reallexikon der Assyriologie und Vorderasiatischen Archäologie 6: Klagegesang - Libanon. De Gruyter, Berlin, New-York: 609-640.

Chalendar V. (in press) - Taxonomy and Medicine: analysing transfers between disciplines, a step towards understanding Mesopotamian sciences.

GeLler M. J. 2005. - Renal and rectal disease texts. Die Babylonisch-Assyrische Medizin in Texten und Untersuchungen 7: Renal and Rectal Disease Texts De Gruyter, Berlin, New-York, $\mathrm{viii}+284 \mathrm{p}$

Geller M. 2010. - Ancient Babylonian Medicine, Theory and Practice. Willey-Blackwell, Chichester, 221 p.
Heessel N. 2000. - Babylonisch-assyrische Diagnostik. Alter Orient und Altes Testament 43, xxi $+471 \mathrm{p}$.

Heide M. 2008. - Das Buch der Hippiatrie - Kitāb al-Bayṭara von Muḥammad Ibn-Ya qūb Ibn-Ahīi-Hizām. Veröffentlichungen der Orientalischen Kommission 51, 380 p.

HeImpel W. 1987. - Maus, in EdZARD D. (ed.), Reallexikon der Assyriologie und Vorderasiatischen Archäologie 7: 605-609.

Herrero P. 1984. - La Thérapeutique Mésopotamienne. Éditions Recherche sur les Civilisations, Paris, 139 p.

KINNIER WILSON J. 2005. — Notes on the assyrian pharmaceutical series URU.AN.NA: Maštakal. Journal of Near Eastern Studies 64 (1): 45-51.

KÖCHER F. 1995. - Ein Text medizinischen Inhalts aus dem neubabylonischen Grab 405, in BOEHMER R. M. (ed.), Ausgrabungen in Uruk-Warka: Endberichte 10: 203-217.

Kogan L. \& MilitareV A. 2005. - Semitic etymological dictionary. Volume 2: Animal names. Alter Orient und Altes Testament 278 (2), 415 p.

LANDSBERger B. 1934. - Die Fauna des alten Mesopotamien nach der 14. Tafel der Serie Har-ra = hubullu. Abhandlungen der philologisch-historischen Klasse der Sächsischen Akademie der Wissenschaften 42 (6), $144 \mathrm{p}$.

LANDSBERGER B. 1960. - The fauna of ancient Mesopotamia, first part, tablet XIII. Materialien Zum Sumerischen Lexicon VIII (1), $103 \mathrm{p}$.

LANDSBERGER B. 1962. - The fauna of ancient Mesopotamia, second part, HAR-ra $=$ Hubullu tablets XIV and XVIII. Materialien Zum Sumerischen Lexicon VIII (2), 180 p.

Lion B. \& Michel C. 2000. - Poissons et crustacés en Haute Mésopotamie au début du IIe millénaire av. J.-C., in Les Animaux et les Hommes dans le Monde Syro-Mésopotamien aux Époques Historiques. 21e Colloque International, 4-5 décembre 1998, Université Charles de Gaulle Lille III. TopoïSuppl. 2: 71-116.

LION B. et al. 2000. - Les crevettes dans la documentation du Proche-Orient ancien. Journal of Cuneiform Studies 52: 55-60.

Loretz O. 2011. - Das Pferd in Kultur, Wirtschaft, Kriegführung und Hippiatrie Ugarits: Pferd, Esel und Kamel in biblischen Texten. Alter Orient und Altes Testament 386, xvii +496 p.

MCCABE A. 2007. - A Byzantine Encyclopaedia of Horse Medicine: the Sources, Compilations, and Transmission of the Hippiatrica. Oxford University Press, Oxford, 347 p.

Nougayrol J. 1972. - Textes religieux (II). Revue d'Assyriologie et d'Archéologie orientale 66 (2): 141-145. http://www.jstor.org/ stable/23295863

PientKa-Hintz R. 2004. - Aus Der Wüste Ins Schlafzimmer der Skorpion, in Nicolle C. (ed.), Nomades et sédentaires dans le Proche-Orient ancien: Compte Rendu de la XLVIe Rencontre Assyriologique Internationale (Paris 10-13 Juillet 2000). Amurru 3: 389-404

Pedersén O. 1998. - Archives and Libraries in the Ancient Near East 1500-300 BC. CDL Press, Bethesda, 291 p.

SAlonen A. 1970. - Die Fischerei im alten Mesopotamien : nach sumerisch-akkadischen Quellen. Suomalainen tiedeakatemia, Helsinki, 314 p.

SALONEN A. 1973. - Vögel und Vogelfang im alten Mesopotamien. Suomalainen tiedeakatemia, Helsinki, 374 p.

SALONEN A. 1976. - Jagd und Jagdtiere im alten Mesopotamien. Suomalainen tiedeakatemia, Helsinki, 312 p.

SCURLOCK J. 2002. - Translating transfers in ancient Mesopotamia, in MeYer M. \& MireCKI P. (eds), Magic and Ritual in the Ancient World. Brill, Leiden, New-York, Köln: 210-223.

SCURLOCK J. 2006. - Magico-medical means of treating ghostinduced illnesses in ancient Mesopotamia. Ancient Magic and Divination 3, 788 p.

SCURLOCK J. 2014. - Sourcebook for ancient Mesopotamian medicine. Writings from the Ancient World 36, $764 \mathrm{p}$.

STADHOUDERS H. 2011. - The pharmacopoeial handbook Šammu Šikinšu : an edition. Journal des Médecines cunéiformes 18: 3-51. 
STADHOUdERS H. 2012. - The pharmacopoeial handbook Šammu Šikinšu : a translation. Journal des Médecines cunéiformes 19: 1-21.

STOL M. 2011. — Pferde, Pferdekrankheiten und Pferdemedizin in altbabylonischer Zeit, in LORETz O., Das Pferd in Kultur, Wirtschaft, Kriegführung und Hippiatrie Ugarits: Pferd, Esel und Kamel in biblischen Texten. Alter Orient und Altes Testament (386): 363-402.
STRECK M. 2014. - Tierwelt, in EdZARD D. (ed.), Reallexikon der Assyriologie und Vorderasiatischen Archäologie 14 (1): 16-19.

VELDHUIS N. 2014. - History of the cuneiform lexical tradition. Guides to the Mesopotamian Textual Record 6, 524 p.

VERDERAME L. 2013. - Means of substitution: the use of figurines, animals, and human beings as substitutes in assyrian rituals. Rivista Studi Orientali Suppl. 2: 301-323.

Submitted on 3rd April 2016, accepted on 4 July 2016; published on 30 December 2016. 